\title{
ANALISIS PERHITUNGAN DAN PENCATATAN PPH PASAL 23 DAN PELAPORAN PPH PASAL 25 PADA PT. BANK SULUT CABANG UTAMA
}

\author{
Cisilia Lumunon \\ David Paul Elia Saerang \\ Inggriani Elim
}

\author{
Fakultas Ekonomi dan Bisnis Jurusan Akuntansi \\ Universitas Sam Ratulangi Manado \\ email: cisilialumunon@yahoo.co.id
}

\begin{abstract}
ABSTRAK
Pajak penghasilan pasal 23 (PPh Pasal 23), yaitu pemotongan pajak atas penghasilan yang diterima atau diperoleh Wajib Pajak dalam negeri dan Bentuk Usaha Tetap yang berasal dari modal, penyerahan jasa atau penyelenggaraan kegiatan selain yang telah dipotong Pajak Penghasilan Pasal 21, yang dibayarkan, disediakan, untuk dibayarkan, atau telah jatuh tempo pembayarannya oleh badan pemerintah, subjek pajak dalam negeri, penyelenggara kegiatan, bentuk usaha tetap, perwakilan perusahaan luar negeri lainnya. Sedangkan PPh Pasal 25 adalah angsuran pajak penghasilan yang harus dibayar sendiri oleh Wajib Pajak untuk setiap bulan dalam tahun pajak berjalan. Penelitian ini bertujuan untuk mengetahui besarnya Pajak Penghasilan Pasal 23 dan Pajak Penghasilan Pasal 25 yang disetorkan dan untuk mengetahui apakah perhitungan dan pencatatan Pajak Penghasilan Pasal 23 dan Pelaporan Pajak Penghasilan Pasal 25 Pada PT. Bank Sulut Cabang Utama sudah sesuai dengan Undang-undang tentang Pajak Penghasilan. Objek penelitian diambil pada PT. Bank Sulut Cabang Utama. Metode penelitian yang digunakan adalah metode analisis deskriptif. Dari hasil penelitian dapat disimpulkan bahwa Perhitungan dan Pencatatan PPh Pasal 23 dan Pelaporan PPh Pasal 25 sudah sesuai dengan ketentuan yang berlaku.
\end{abstract}

Kata kunci : pph pasal 23, pph pasal 25.

\section{ABSTRACT}

Income tax article 23 ( article 23 ), is withholding tax on income derived by a taxpayer in domestically and Permanent Establishment derived from the capital , organizing the delivery of services or activities other than those of Article 21 Income Tax withheld, paid, supplied, to be paid, or was due for payment by government agencies, subject to tax in domestically, organizers of the event, the permanent establishment , representatives of other foreign companies. While the Income Tax Article 25 is that income tax installment must be paid by the taxpayer for any month in the current tax year. This study aims to determine the amount of income tax Article 23 and Income Tax Article 25 are deposited and to know whether the calculation and recording of income tax under Article 23 and Article 25 of the Income Tax Reporting at PT. Bank Sulut Main Branch is in conformity with the Law on Income Tax. The object of research is taken at PT. Bank Sulut Main Branch. The method used is descriptive analysis method. From the results of this study concluded that the calculation and recording of article 23 and article 25 of Income Tax Reporting was in accordance with applicable regulations.

Keywords : Income tax article 23, Income tax article 25. 


\section{PENDAHULUAN}

\section{Latar Belakang}

Terdapat beberapa cara dalam menghitung pajak. Salah satu cara dalam perhitungan pajak adalah dengan self assessment system. Kendati demikian, self assessment system ini memiliki beberapa kelemahan. Untuk melengkapi dan menutup kelemahan yang ada pada self assessment system digunakan sistem perpajakan yang lain yaitu sistem pemotongan (withholding system). Withholding system adalah suatu cara pemungutan pajak yang penghitungan besarnya pajak yang terutang oleh Wajib Pajak dilakukan oleh pihak ketiga.

Salah satu pajak yang menggunakan withholding system adalah Pajak Penghasilan Pasal 23 (PPh Pasal 23), yaitu pemotongan pajak atas penghasilan yang diterima atau diperoleh Wajib Pajak dalam negeri dan Bentuk Usaha Tetap yang berasal dari modal, penyerahan jasa atau penyelenggaraan kegiatan selain yang telah dipotong Pajak Penghasilan Pasal 21, yang dibayarkan, disediakan, untuk dibayarkan, atau telah jatuh tempo pembayarannya oleh badan pemerintah, subjek pajak dalam negeri, penyelenggara kegiatan, bentuk usaha tetap, perwakilan perusahaan luar negeri lainnya.

Adapun perhitungan untuk mengetahui jumlah pajak badan yang terutang diatur dalam ketentuan $\mathrm{PPh}$ Pasal 25. Dalam ketentuan PPh Pasal 25 diatur tentang angsuran pajak penghasilan yang harus dibayar sendiri oleh Wajib Pajak untuk setiap bulan dalam tahun pajak berjalan.

Oleh karena itu pemerintah bersifat keras dan tegas dalam kewenangannya sebagai pengawas dan pemeriksa terhadap pelaksanaan kewajiban perpajakan yang dilakukan oleh wajib pajak. Akan tetapi dengan adanya self assessment system, ini membuat wajib pajak orang pribadi maupu badan mendapatkan kewenangan untuk menghitung dan melaporkan sendiri kewajiban PPh pasal 25. Ini menjadi suatu permasalahan tersendiri karena dengan melaporkan sendiri PPh Pasal 25 maka setiap perusahaan bukan tidak mungkin akan melakukan penyelewengan pajak atau manipulasi pajak.

Perbankan memegang peranan penting dalam kehidupan masyarakat. Perbankan merupakan perusahaan yang dalam kegiatannya berhubungan langsung dengan masyarakat. Kegiatan perbankan begitu dipengaruhi oleh kepercayaan nasabah atau masyarakat luas. PT. Bank Sulut Cabang Utama merupakan perusahaan yang bergerak di bidang jasa keuangan perbankan. Sebagai perusahaan yang taat akan pajak maka, PT. Bank Sulut berkewajiban untuk melakukan perhitungan dan pencatatan dalam hal ini khususnya Undang-Undang Pajak Penghasilan Pasal 23 serta pelaporan Pajak Penghasilan Pasal 25 sesuai ketentuan yang mengacu pada UndangUndang Perpajakan yang berlaku.

Berdasarkan uraian tersebut, untuk memperoleh gambaran yang lebih jelas tentang perpajakan, khususnya mengenai bagaimana suatu perusahaan menentukan besarnya Pajak Penghasilan dan pencatatannya dalam hal ini PPh Pasal 23 dan yang harus dilaporkan dan disetorkan dalam hal ini PPh Pasal 25, kepada pemerintah dan apakah perhitungan, pencatatan, dan pelaporan Pajak Penghasilan telah sesuai dengan ketentuan yang berlaku, maka penulis mengambil judul "ANALISIS PERHITUNGAN DAN PENCATATAN PPH PASAL 23 DAN PELAPORAN PPH PASAL 25 YANG PADA PT. BANK SULUT CABANG UTAMA."

\section{Tujuan Penelitian}

Adapun tujuan yang hendak penulis capai dalam penelitian ini adalah:

1. Untuk mengetahui perhitungan dan pencatatan PPh Pasal 23 pada PT. Bank Sulut Cabang Utama.

2. Untuk mengetahui pelaporan PPh Pasal 25 pada PT. Bank Sulut Cabang Utama.

\section{TINJAUAN PUSTAKA}

\section{Akuntansi}

Pengertian akuntansi menurut Hongren, dan Harison dalam Akuntansi (2007), adalah "sistem informasi yang mengukur aktivitas bisnis, memroses data menjadi laporan, dan mengomunikasikan hasilnya kepada para pengambil keputusan." Dalam definisi ini pula Horngren dan Harison menyatakan bahwa akuntansi merupakan bahasa bisnis.

Pengertian akuntansi menurut American Institute of Certified Public Accounting (AICPA) dalam Ahmed Riahi Balkaoui mendefinisikan akuntansi sebagai berikut: Akuntansi adalah seni pencatatan, penggolongan dan peringkasan transaksi dan kejadian yang bersifat keuangan dengan cara yang berdaya guna dan dalam bentuk satuan uang dan penginterprestasikan hasil tersebut (Balkaoui, 2000:37). 
Menurut C. Rollin Niswonger, Carl S. Warren, James M. Reeve, Philip E. Fess pengertian akuntansi adalah sebagai berikut: Akuntansi dapat didefinisikan sebagai sistem akuntansi yang menghasilkan laporan kepada pihak-pihak yang berkepentingan mengenai aktivitas ekonomi dan kondisi perusahaan (Niswonger, 1999:6).

Dari definisi-definisi diatas dapat disimpukan bahwa akuntansi mengandung dua hal. Pertama, akuntansi memberikan jasa, maksudnya kita harus memanfaatkan sumber-sumber yang ada (misalnya : sumber daya alam, tenaga kerja dan kekayaan keuangan) dengan bijaksana sehingga kita dapat memaksimalkan manfaat bagi kesejahteraan masyarakat, semakin baik system akuntansi yang mengukur dan melaporkan biaya penggunaan sumber daya tersebut, maka akan semakin baik juga keputusan yang di ambil untuk mengalokasikannya. Kedua, akuntansi menyediakan informasi kauangan yang bersifat kuantitatif yang di gunakan dalam kaitannya dengan evaluasi kualitatif dalam membuat perhitungan. Sehingga informasi masa lalu yang disediakan akan bermanfaat dalam pengambilan keputusan ekonomi masa mendatang.

\section{Pajak Penghasilan Pasal 23}

Mardiasmo (2011), "Ketentuan dalam pasal 23 UU PPh mengatur pemotongan pajak atas penghasilan yang diterima atau diperoleh Wajib Pajak dalam negeri dan Bentuk Usaha Tetap yang berasal dari modal, penyerahan jasa atau penyelenggaraan kegiatan selain yang telah dipotong Pajak Penghasilan Pasal 21, yang dibayarkan, disediakan, untuk dibayarkan, atau telah jatuh tempo pembayarannya oleh badan pemerintah, subjek pajak dalam negeri, penyelenggara kegiatan, bentuk usaha tetap, perwakilan perusahaan luar negeri lainnya."

\section{Cara menghitung PPh Pasal 23}

Cara menghitung PPh Pasal 23 atas dividen :

PPh Pasal $23=15 \%$ x Bruto (Penghasilan kotor)

Cara menghitung PPh Pasal 23 atas bunga, termasuk premium, diskonto, dan imbalan karena jaminan pengembalian utang :

PPh Pasal $23=15 \% \times$ Bruto (Penghasilan kotor)

Cara menghitung PPh Pasal 23 atas royalti :

PPh Pasal $23=15 \%$ x Bruto (Penghasilan kotor)

Cara menghitung PPh Pasal 23 atas hadiah, penghargaan, bonus, dan sejenisnya :

PPh Pasal 23 $=15 \% \times$ Bruto (Penghasilan kotor)

Cara menghitung PPh Pasal 23 atas sewa dan penghasilan lain sehubungan dengan penggunaan harta :

PPh Pasal $23=2 \% \times$ Bruto (Penghasilan kotor)

Cara menghitung PPh Pasal 23 atas imbalan sehubungan dengan jasa teknik, jasa manajemen, jasa konstruksi, jasa konsultan, dan jasa lain :

PPh Pasal $23=2 \% \times$ Bruto (Penghasilan kotor)

\section{Pajak Penghasilan Pasal 25}

Pajak penghasilan pasal 25 adalah angsuran perusahaan yang dibayarkan perusahaan setiap bulannya sebagai uang muka pajak PPh pasal 25 yang akan diperhitungkan pada akhir masa pembukuan.

\section{Tatacara Pelaporan PPh Pasal 25}

Pembayaran PPh Pasal 25 harus dilakukan paling lambat tanggal 15 bulan berikutnya, dan pelaporannya paling lambat tanggal 20 bulan berikutnya setelah masa pajak berakhir. Menurut Peraturan Dirjen Pajak No.PER-22/PJ/2008 bahwa pembayaran PPh Pasal 25 melalui modul penerimaan negara (MPN) dan SSP PPh Pasal 25 yang telah mendapat validasi NTPN (nomor transaksi penerimaan Negara) dari bank, maka Wajib Pajak dianggap telah melakukan pelaporan PPh Pasal 25. 


\section{Penelitian Terdahulu}

Tabel 1. Matriks Perbandingan Penelitian ini dengan penelitian terdahulu

\begin{tabular}{|c|c|c|c|c|c|c|}
\hline $\begin{array}{l}\text { Nama } \\
\text { Peneliti } \\
\text { / tahun }\end{array}$ & Judul & Tujuan & $\begin{array}{c}\text { Metode } \\
\text { Penelitian }\end{array}$ & Hasil penelitian & persamaan & perbedaan \\
\hline $\begin{array}{c}\text { Kusuma } \\
(2010)\end{array}$ & $\begin{array}{l}\text { Prosedur } \\
\text { perhitungan } \\
\text { dan } \\
\text { pelaporan } \\
\text { PPh pasal } 23 \\
\text { Atas Komisi } \\
\text { Agen } \\
\text { Penjualan } \\
\text { Tiket Pada } \\
\text { PT. Garuda } \\
\text { Indonesia. }\end{array}$ & $\begin{array}{l}\text { Untuk membahas } \\
\text { perhitungan PPh } 23 \\
\text { di komisi Agen } \\
\text { Penjualan Tiket } \\
\text { Pada PT. Garuda } \\
\text { Indonesia. }\end{array}$ & $\begin{array}{l}\text { Kuantitatif } \\
\text { Deskriptif }\end{array}$ & $\begin{array}{l}\text { Penerpan PPh } 23 \text { sudah } \\
\text { dilakukan dengan baik } \\
\text { dan benar. }\end{array}$ & $\begin{array}{l}\text { Meneliti } \\
\text { perhitungan } \\
\text { PPh Pasal } 23 .\end{array}$ & $\begin{array}{l}\text { Objek yang di } \\
\text { teliti bukan } \\
\text { perusahaan } \\
\text { perbankan. } \\
\text { Penelitian hanya } \\
\text { dilakukan untuk } \\
\text { perhitungan PPh } \\
23 \text {. }\end{array}$ \\
\hline $\begin{array}{l}\text { Idris } \\
\text { (2006) }\end{array}$ & $\begin{array}{l}\text { Perhitungan } \\
\text { dan Perlakuan } \\
\text { Akuntansi } \\
\text { Pajak } \\
\text { Penghasilan } \\
\text { Pasal } 21 \text { dan } \\
\text { Pajak } \\
\text { Penghasilan } \\
\text { Pasal 25 Pada } \\
\text { CV. Haltim } \\
\text { Raya Ternate. }\end{array}$ & $\begin{array}{l}\text { Untuk membahas } \\
\text { perhitungan dan } \\
\text { perlakuan } \\
\text { akuntansi PPh } \\
\text { pasal } 21 \text { dan pasal } \\
25 \text { pada CV. } \\
\text { Haltim Raya } \\
\text { ternate. }\end{array}$ & $\begin{array}{l}\text { Kuantitatif } \\
\text { Deskriptif. }\end{array}$ & $\begin{array}{l}\text { Perhitungan dan } \\
\text { Perlakuan Akuntansi } \\
\text { PPh Pasal } 21 \text { dan PPh } \\
\text { Pasal 25 Pada CV. } \\
\text { Haltim Raya Ternate. } \\
\text { Telah dilakukan dengan } \\
\text { tepat. }\end{array}$ & $\begin{array}{l}\text { Meneliti PPh } \\
\text { pasal } 25 .\end{array}$ & $\begin{array}{l}\text { Objek penelitian } \\
\text { bukan perusahaan } \\
\text { perbankan. } \\
\text { Menitik beratkan } \\
\text { pada } \mathrm{PPh} 21 .\end{array}$ \\
\hline
\end{tabular}

\section{METODE PENELITIAN}

\section{Jenis Penelitian}

Jenis penelitian ini adalah deskriptif. Penelitian deskriptif merupakan penelitian terhadap masalahmasalah berupa fakta-fakta saat ini dari suatu populasi ( Indriantoro dan Supomo, 2012: 26)

\section{Tempat dan Waktu Penelitian}

Tempat Penelitian adalah di PT. Bank Sulut Cabang Utama. Dan waktu penelitian selama kirakira 3 bulan.

\section{Prosedur Penelitian}

1. Merumuskan masalah yang ditemui untuk kemudian dapat diteliti dan dicari solusinya.

2. Mengajukan Permohonan Penelitian dengan cara memasukan surat permohonan penelitian dengan persetujuan dari Fakultas Ekonomi untuk melakukan penelitian pada objek atau instansi yang dipakai dalam penyusunan skripsi.

3. Disposisi Pimpinan Instansi yaitu setelah pemasukan surat permohonan penelitian, Bidang Umum dan Kerjasama, menindak lanjuti pembuatan surat perintah yang menjelaskan tentang izin penelitian pada instansi tersebut dengan persetujuan pimpinan instansi.

4. Pengumpulan informasi dengan mencari berbagai literatur dari berbagai sumber, seperti di perpustakaan, yang terkait dengan pokok masalah yang dibahas oleh peneliti, demi lancarnya proses penyusunan skripsi ini. Juga, melalui media elektronik, berupa akses data dalam internet untuk melengkapi teori-teori yang ada untuk lebih memahami permasalahan yang ditemui.

5. Mencari data secara langsung yang diperoleh dari PT. Bank Sulut Cabang Utama.

6. Melakukan peneletian dan pembahasan berdasarkan data yang telah didapatkan sebelumnya dan mengkaji kembali apakah sesuai dengan teori-teori yang telah ada.

7. Menarik kesimpulan serta memberikan saran dari penulis sesuai dengan hasil penelitian dan pembahasan, apakah permasalahan yang telah dibahas tersebut memiliki dampak bagi perusahaan itu sendiri. 


\section{Metode Pengumpulan Data \\ Jenis Data}

Data adalah sekumpulan fakta yang diperoleh melalui pengamatan (observasi) langsung atau survei (Indriantoro dan Supomo, 2012: 10). Dalam penelitian ini menggunakan dua jenis data yaitu:

a. Data Kuantitatif adalah data penelitian berupa angka-angka atau numerik dan analisis menggunakan statistik.

b. Data Kualitatif adalah data yang disajikan secara deskriptif dan tidak dapat diukur dengan skala numerik.

\section{Sumber Data}

1. Data Primer, merupakan sumber data penelitian yang diperoleh secara langsung dari sumber asli atau tidak melalui media perantara (Indriantoro dan Supomo, 2012: 146).

2. Data Sekunder, merupakan sumber data penelitian yang diperoleh peneliti secara tidak langsung melalui media perantara atau diperoleh dan dicatat oleh pihak lain (Indriantoro dan Supomo, 2012: 147).

\section{Teknik Pengumpulan Data}

1. Teknik wawancara, yaitu dengan melakukan wawancara kepada pihak-pihak terkait dengan penyediaan informasi atau data yang diperlukan dalam penelitian.

2. Teknik Dokumentasi, yaitu dengan melakukan penelusuran terhadap dokumen-dokumen perusahaan yang mendukung keperluan penelitian.

3. Penelitian Lapangan, melalui penelitian ini dikumpulkan data-data langsung dari sumber data sebagai perbandingan untuk memperoleh keterangan dan kenyataan yang sebenarnya.

\section{Metode Analisis}

Metode analisis data yang digunakan penelitian ini adalah metode analisis deskriptif dimana penelitian dilakukan dengan mengumpulkan, dan menganalisa data yang dikumpulkan serta memberi keteranganketerangan yang dihadapi.

\section{HASIL PENELITIAN DAN PEMBAHASAN}

\section{Gambaran Umum Objek Penelitian}

PT. Bank Sulut (Bank) dahulu bernama PT. Bank Pembangunan Daerah Sulawesi Utara didirikan dengan nama Bank Pembangunan Daerah Sulawesi Utara Tengah berdasarkan Akte no. 88 tanggal 17 Maret 1961 oleh Raden Hadiwido, notaris pengganti dari Raden Kadiman, Notaris di Jakarta yang diperbaiki dengan Akte Perubahan Anggaran Dasar No. 22 tanggal 4 Agustus 1961 oleh Raden Kadiman Notaris di Jakarta dan Akta Perubahan Anggaran Dasar No. 46 tanggal 10 Oktober 1961 oleh Raden Hadiwido pengganti dari Raden Kadiman, notaris di Jakarta, yang telah memperoleh pengesahan dari Menteri Kehakiman Republik Indonesia dengan penetapan No. J.A.5/109/6 tanggal 13 Oktober 1961.

Modal Dasar ditetapkan sebesar Rp. 100 milyar dengan kepemlikan Daerah Propinsi, Kabupaten dan Kota pemegang saham Seri A maksimum sebesar $55 \%$ dan pemegang saham seri B bersama-sama dengan pihak ketiga termasuk koperasi maksimum sebesar $45 \%$. Saham-saham terbagi atas Saham Seri A sebanyak 550.000 nilai nominal @ Rp. 100.000,- (Seratus ribu rupiah) dan Saham Seri B sebanyak 450.000 nilai niminal @ Rp. 100.000,- (Seratus ribu rupiah). Perubahan bentuk badan hukum Bank Sulut tersebut merupakan tuntutan dalam rangkam memenuhi salah satu persyaratan mengikuti program rekapitalisasi perbankan karena Bank Sulut menghadapi risiko kewajiban pemenuhan modal minimum (KPPM) kurang dari $8 \%$.

Setelah Bank Sulut melepaskan diri dari program rekapitalisasi perbankan terjadi beberapa perubahan Anggaran Dasar berkaitan dengan perubahan susunan kepemilikan saham setelah divestasi saham negara, dan terakhir dengan peningkatan modal dasar dari Rp. 100 milyar menjadi Rp. 300 milyar yang telah mendapat persetujuan Menteri Hukum dan Hak Asasi Manusia RI No.C-24640 HT.01.04.TH.2006 tanggal 23 Agustus 2006 telah diumumkan dalam Berita Negara RI tanggal 23 Oktober 2006 No. 85 Tambahan No. 11432/2006. 


\section{Hasil Penelitian}

Tabel 2. Perhitungan PPh Pasal 23 pada PT. BANK SULUT CABANG UTAMA

\begin{tabular}{|c|c|c|c|c|c|}
\hline NO & $\begin{array}{c}\text { Tanggal } \\
\text { pemotongan }\end{array}$ & Pemotong pajak & $\begin{array}{l}\text { Objek pemotongan } \\
(\mathrm{Rp})\end{array}$ & $\begin{array}{r}\text { Tarif } \\
\text { pajak }\end{array}$ & $\begin{array}{c}\text { PPh pasal } 23 \\
\text { (Rp) }\end{array}$ \\
\hline 1 & $27-06-2013$ & $\begin{array}{l}\text { PPh pasal } 23 \text { atas jasa } \\
\text { perbaikan AC split } \\
\text { dan pasang coban } \\
\text { dicabang utama }\end{array}$ & Rp. 3.781.250 & $2 \%$ & Rp. 75.625 \\
\hline 2 & 08-07-2013 & $\begin{array}{l}\text { PPh pasal } 23 \text { Atas } \\
\text { jasa perbaikan dan } \\
\text { service AC split di } \\
\text { ATM kk Walikota } \\
\text { dan Gubernur }\end{array}$ & Rp. 2.218.150 & $2 \%$ & Rp. 44.375 \\
\hline 3 & $25-07-2013$ & $\begin{array}{l}\text { PPh pasal 23 Atas } \\
\text { jasa perbaikan alat } \\
\text { untuk ganti AC split } \\
\text { di kk Marina }\end{array}$ & Rp. 3.656.250 & $2 \%$ & Rp. 73.125 \\
\hline 4 & $30-08-2013$ & $\begin{array}{l}\text { PPh pasal } 23 \text { Atas } \\
\text { jasa petugas polisi } \\
\text { untuk pengamanan di } \\
\text { cabang utama } \\
\text { peragustus } 2013\end{array}$ & Rp. 6.250 .000 & $2 \%$ & Rp. 125.000 \\
\hline 5 & $30-08-2013$ & $\begin{array}{l}\text { PPh pasal 23 Atas } \\
\text { jasa perbaikan AC } \\
\text { split tranding } \\
\text { cabang utama }\end{array}$ & Rp. 3.250 .000 & $2 \%$ & Rp. 65.000 \\
\hline
\end{tabular}

Sumber : Hasil olahan data

Pada bulan Juni, Juli dan Agustus tahun 2013, terdapat 5 pemotongan PPh Pasal 23 yang dilakukan oleh PT. Bank Sulut Cabang Utama dalam rangka memperbaiki fasililitas serta memperketat keamanan demi kenyamanan semua pihak. Berikut adalah rincian perhitungan PPh Pasal 23 yang dimiliki oleh PT. Bank Sulut Cabang Utama :

1. Pada tanggal 27 juli 2013, PT. Bank Sulut Cabang Utama membayarkan jasa perbaikan AC split dan pasang coban dicabang utama sebesar Rp. 3.781.250. PPh Pasal 23 yang dipotong oleh PT. Bank Sulut Cabang Utama adalah :

$$
2 \% \mathrm{x} \text { Rp. 3.781.250 = Rp.75.625 }
$$

2. Di bulan selanjutnya, tepat pada tanggal 8 juli 2013, PT. Bank Sulut Cabang Utama kembali melakukan perbaikan dan service AC split namum kali ini bertempat di ATM kk Walikota dan Gubernur. PT. Bank Sulut Cabang Utama kemudian harus membayar jasa untuk perbaikan tersebut sebesar Rp. 2.218.150. PPh Pasal 23 yang dipotong oleh PT. Bank Sulut Cabang Utama adalah :

$$
2 \% \quad \mathrm{x} \quad \text { Rp. } 2.218 .150 \quad=\quad \text { Rp. } 44.375
$$

3. Terjadi kerusakan AC split di kk Marina pada tanggal 25 Juli 2013 sehingga PT. Bank Sulut Cabang Utama harus melakukan pergantian alat untuk AC d kk Mariana tersebut. Dan PT. Bank Sulut Cabang Utama kembali harus membayar jasa service sebsesar Rp. 3.656.250. PPh Pasal 23 yang dipotong oleh PT. Bank Sulut Cabang Utama adalah :

$$
2 \% \times \text { Rp. 3.656.250 = Rp.73.125 }
$$

4. Atas jasa petugas polisi untuk pengamanan di cabang utama per-agustus 2013, PT Bank Sulut Cabang Utama harus melakukan pembayaran sebesar Rp. 6.250.000. PPh Pasal 23 yang dipotong oleh PT. Bank Sulut Cabang Utama adalah :

$$
2 \% \mathrm{x} \quad \text { Rp. } 6.250 .000 \quad \text { Rp. } 125.000
$$

5. Pengeluaran yang terakhir pada bulan agustus dilakukan PT. Bank Sulut Cabang Utama atas jasa perbaikan AC split tranding di cabang utama sebesar Rp. 3.250.000. PPh Pasal 23 yang dipotong oleh PT. Bank Sulut Cabang Utama adalah :

$$
2 \% \quad \mathrm{x} \quad \text { Rp. } 3.250 .000 \quad=\quad \text { Rp. } 65.000
$$




\section{Pelaporan PPh Pasal 25 Pada PT. Bank Sulut Cabang Utama}

PT. Bank Sulut Cabang Utama Manado memiliki pelaporan PPH pasal 25. Berikut adalah rician pelaporan beserta besarnya PPh Pasal 25 yang harus di bayarkan setiap bulannya oleh PT. Bank Sulut Cabang Utama Manado.

Tabel 3. Pelaporan PPh Pasal 25 Pada PT. Bank Sulut Cabang Utama

\begin{tabular}{cc}
\hline Masa Pajak & Jumlah ( Rp ) \\
\hline Januari & Rp. 5.066.311.000 \\
Februari & Rp. 5.066.311.000 \\
Maret & Rp. 5.066.311.000 \\
April & Rp. 8.723.118.000 \\
Mei & Rp. 8.723.118.000 \\
Juni & Rp. 8.723.118.000 \\
Juli & Rp. 6.747 .000 .000 \\
Agustus & Rp. 6.747.000.000 \\
September & Rp. 6.747.000.000 \\
Oktober & Rp. 5.290.000.000 \\
\hline
\end{tabular}

Sumber : PT. Bank Sulut Cabang Utama

PT. Bank Sulut Cabang Utama harus membayarkan angsuran PPh Pasal 25 untuk masa pajak Januari s/d Maret tahun 2013 sebesar Rp. 5.066.311.000, masa pajak April s/d Juni tahun 2013 sebesar Rp. 8.723.118.000, masa pajak Juli s/d Agustus tahun 2013 sebesar Rp. 6.747.000.000, dan masa pajak September s/d Oktober tahun 2013 sebesar Rp. 5.290.000.000.

\section{Pembahasan}

\section{Analisis Perhitungan dan Pencatatan PPh Pasal 23}

Dari rincian perhitungan PPh Pasal 23 yang dimiliki oleh PT. Bank Sulut Cabang Utama, dapat dilihat bahwa pemotongan PPh Pasal 23 yang tertinggi dilakukan pada saat pembayaran atas jasa petugas polisi untuk pengamanan di cabang utama per-agustus 2013 dengan perhitungan ( $2 \%$ x Rp. 6.250.000 = Rp. 125.000 ). Jadi PPh Pasal 23 yang dipotong oleh PT. Bank Sulut Cabang Utama pada tanggal 30 Agustus 2013 adalah sebesar Rp. 125.000. Dan yang terendah dilakukan pada saat perbaikan dan service AC split di ATM kk Walikota dan Gubernur dengan perhitungan ( $2 \%$ x 2.218.150 = Rp. 44.375 ). Jadi PPh Pasal 23 yang dipotong oleh PT. Bank Sulut Cabang Utama pada tanggal 8 Ju;i 2013 adalah sebesar Rp. 44.375 . Total pemotongan PPh Pasal 23 yang dilakukan oleh PT. Bank Sulut Cabang Utama pada bulan Juni, Juli dan Agustus tahun 2013 adalah Rp. 383.125. Pelaporan harus di lakukan perbulan dan harus diterbitkan bukti pemotongan pajak PPh Pasal 23 yang sah.

PT. Bank Sulut Cabang Utama akan melalukan pencatatan untuk masing-masing transaksi PPh Pasal 23 sebagai berikut :

1. PPh Pasal 23 atas jasa perbaikan AC split dan pasang coban dicabang utama pada tanggal 27 Juni 2013.

Biaya service

Kas

( Mencatat Pengeluaran atas Jasa Perbaikan )

Kas

Hutang PPh Pasal 23

( Mencatat Pemungutan PPh Pasal 23 )

Hutang PPh Pasal 23

Kas

( Mencatat Pembayaran PPh Pasal 23 )
Rp. 3.781.250

$$
\text { Rp. } 3.781 .250
$$

Rp. 75.625

Rp. 75.625

Rp. 75.625

Rp. 75.625

2. PPh pasal 23 atas jasa perbaikan dan service AC split di ATM kk Walikota dan Gubernur pada tanggal 8 Juli 2013.

Biaya service

Kas
Rp. 2.218 .150

Rp. 2.218 .150 
( Mencatat Pengeluaran atas Jasa Perbaikan )

Kas

Hutang PPh Pasal 23

Rp. 44.375

( Mencatat Pemungutan PPh Pasal 23 )

Hutang PPh Pasal 23

Kas

Rp. 44.375

Rp. 44.375

Rp. 44.375

( Mencatat Pembayaran PPh Pasal 23 )

3. PPh pasal 23 Atas jasa perbaikan alat untuk ganti AC split di kk Marina pada tanggal 25 Juli 2013.

Biaya service Rp. 3.656.250

Kas

Rp. 3.656.250

( Mencatat Pengeluaran atas Jasa Perbaikan )

Kas

Hutang PPh Pasal 23

Rp. 73.125

Rp. 73.125

( Mencatat Pemungutan PPh Pasal 23 )

Hutang PPh Pasal 23

Rp. 73.125

Kas

( Mencatat Pembayaran PPh Pasal 23 )

Rp. 73.125

4. $\mathrm{PPh}$ pasal 23 Atas jasa petugas polisi untuk pengamanan di cabang utama peragustus 2013.

Biaya keamanan

Kas

( Mencatat Pengeluaran atas Jasa Keamanan )

Kas

Hutang PPh Pasal 23

( Mencatat Pemungutan PPh Pasal 23 )

Hutang PPh Pasal 23

Kas

( Mencatat Pembayaran PPh Pasal 23 )
Rp. 6.250 .000

Rp. 6.250 .000

Rp. 125.000

Rp. 125.000

5. $\mathrm{PPh}$ pasal 23 atas jasa perbaikan AC split tranding di cabang utama pada tanggal 30 Agustus 2013.

Biaya Service

( Mencatat Pengeluaran atas Jasa Perbaikan )

Kas

Hutang PPh Pasal 23

( Mencatat Pemungutan PPh Pasal 23 )

Hutang PPh Pasal 23

Kas

( Mencatat Pembayaran PPh Pasal 23 )

PPh Pasal 23 PT. Bank Sulut Cabang Utama bulan Juni, Juli dan Agustus tahun 2013 sebesar Rp. 383.125 yang pelunasannya paling lambat tanggal 10 bulan berikutnya dan SPT masa disampaikan paling lambat 20 hari setelah masa pajak berakhir. Perhitungan dan Pencatatan PPh Pasal 23 bulan Juni, Juli dan Agustus tahun 2013 yang dibuat oleh penulis dengan perhitungan yang dibuat oleh PT. Bank Sulut Cabang Utama tidak terdapat perbedaan, berarti perusahaan dalam menghitung dan melakukan pencatatan PPh pasal 23 sudah sesuai dengan Undang-Undang No. 36 Tahun 2008.
Rp. 3.250 .000

Rp. 3.250 .000

Rp. 65.000

Rp. 65.000

Rp. 65.000
Rp. 65.000

Kas 
Tabel 4. Rincian Pelaporan PPh Pasal 25 PT. Bank Sulut Cabang Utama dari bulan Januari sampai bulan Oktober tahun 2013

\begin{tabular}{ccc}
\hline Masa Pajak & Jumlah ( Rp ) & Tanggal pelaporan \\
\hline Januari & Rp. 5.066.311.000 & 15-Februari-2013 \\
Februari & Rp. 5.066.311.000 & 15-Maret-2013 \\
Maret & Rp. 5.066.311.000 & 15-April-2013 \\
April & Rp. 8.723.118.000 & 15-Mei-2013 \\
Mei & Rp. 8.723.118.000 & 14-Juni-2013 \\
Juni & Rp. 8.723.118.000 & 12-Juli-2013 \\
Juli & Rp. 6.747.000.000 & 15-Agustus-2013 \\
Agustus & Rp. 6.747.000.000 & 13-September-2013 \\
September & Rp. 6.747.000.000 & 15-Oktober-2013 \\
Oktober & Rp. 5.290.000.000 & 14-Novemeber-2013 \\
\hline
\end{tabular}

Sumber : PT. Bank Sulut Cabang Utama

Dari bulan Januari sampai bulan Oktober tahun 2013 angsuran PPh Pasal 25 yang harus dibayarkan PT. Bank Sulut berbeda setiap triwulannya. Untuk masa pajak Januari s/d Maret tahun 2013 sebesar Rp. 5.066.311.000, masa pajak April s/d Juni tahun 2013 sebesar Rp. 8.723.118.000, masa pajak Juli s/d Agustus tahun 2013 sebesar Rp. 6.747.000.000, dan masa pajak September s/d Oktober tahun 2013 sebesar Rp. 5.290.000.000.

PT. Bank Sulut Cabang Utama sendiri melakukan pembayaran angsuran PPh Pasal 25 secara bersamaan dengan pelaporannya.

Pelaporan yang dilakukan oleh PT. Bank Sulut Cabang utama setiap bulannya yaitu pada bulan Januari tahun 2013 dilakukan pada tanggal 15 Februari tahun 2013, begitu pula dengan bulan februari tahun 2013, pelaporan dilakukan pada tanggal 15 Maret tahun 2013, pada bulan selanjutnya yaitu bulan Maret tahun 2013 dilakukan pelaporan pada tanggal 15 April tahun 2013 dan untuk bulan April tahun 2013 dilakukan pelaporan pada tanggal 14 Mei tahun 2013 namun untuk bulan Mei tahun 2013. Pelaporan PPh pasal 25 dilakukan pada tanggal 14 Juni tahun 2013, hal ini dikarenakan tanggal 15 jatuh pada bukan hari kerja sehingga PT. Bank Sulut Cabang Utama memanjukan tanggal pelaporan PPh Pasal 25 yang terutang. Karena apabila tanggal pelaporan dan penyetoran tersebut jatuh pada hari libur atau tanggal merah, maka tanggal pelaporan dan penyetoran dapat digeser pada hari kerja. Begitu pula dengan bulan Juni tahun 2013, pelaporan dilakukan pada tanggal 12 Juli tahun 2013. Untuk bulan Juli tahun 2013 pelaporannya kembali dilakukan pada tanggal 15 Agustus tahun 2013. Dan pada bulan Agustus tahun 2013 pelaporan harus dilakukan lebih awal yaitu tanggal 13 September tahun 2013. Di bulan September tahun 2013 pelaporan kembali dilakukan pada tanggal 15 Oktober tahun 2013. Tapi, pada bulan oktober tahun 2013 pelaporan harus dimajukan pada tanggal 14 November tahun 2013.

PT. Bank Sulut Cabang Utama akan melalukan pencatatan untuk PPh Pasal 25 sebagai berikut :

Pembayaran PPh Pasal 25 misalkan untuk bulan Januari tahun 2013, akan dibayar pada bulan berikut. Untuk itu PT. Bank Sulut Cabang Utama akan melakukan pencatatan seperti :

PPh Pasal 25

Rp. 5.066.311.000

Hutang PPh Pasal 25

Rp. 5.066.311.000

( Mencatat Pengakuan Bulan PPh Pasal 25 bulan Januari Tahun 2013 )

Pada saat pelunasan / pembayaran PT. Bank Sulut Cabang Utama mencatat :

Hutang pajak PPh pasal 25

Rp. 5.066.311.000

Kas

Rp. 5.066 .311 .000

( Mencatat Pembayaran PPh Pasal 25 pada Bulan Berikutnya )

PPh Pasal 25 yang harus dibayarkan PT. Bank Sulut Cabang Utama Untuk masa pajak Januari s/d Maret tahun 2013 sebesar Rp. 5.066.311.000, masa pajak April s/d Juni tahun 2013 sebesar Rp. 8.723.118.000, masa pajak Juli s/d Agustus tahun 2013 sebesar Rp. 6.747.000.000, dan masa pajak September s/d Oktober tahun 2013 sebesar Rp. 5.290.000.000 yang pelunasannya paling lambat tanggal 15 (lima belas) bulan berikutnya dan SPT Masa disampaikan paling lambat 20 hari setelah masa pajak berakhir. Pelaporan PPh Pasal 25 yang dibuat 
penulis dan yang dilakukan oleh PT. Bank Sulut Cabang Utama tidak terdapat perbedaan, berarti PT. Bank Sulut Cabang Utama dalam melaporkan PPh Pasal 25 sudah sesuai dengan ketentuan pajak yang berlaku.

\section{PENUTUP}

\section{Kesimpulan}

Berdasarkan hasil penelitian dan pembahasan yang telah dilakukan maka dapat ditarik beberapa kesimpulan sebagai berikut :

1. Perhitungan dan Pencatatan PPh Pasal 23 yang telah dilakukan oleh PT. Bank Sulut Bank Sulut Cabang Utama pada saat terjadinya transaksi yang berkaitan telah sesuai dengan ketentuan yang berlaku yang terdapat di dalam Undang-undang Nomor 36 Tahun 2008. Namum tak di cantumkannya mitra yang diajak bekerja sama dalam setiap transaksi membuat data yang diterima tidak maksimal.

2. Pelaporan PPh Pasal 25 yang telah dilakukan oleh PT. Bank Sulut Cabang Utama setiap bulannya sudah sesuai dengan Undang-undang Nomor 36 Tahun 2008.

\section{Saran}

Berdasarkan dari kesimpulan, penulis dapat memberikan saran sebagai berikut.

1. Perusahaan dalam hal ini PT. Bank Sulut Cabang Manado sebaiknya menggunakan staf pajak professional ekstern, hal ini dilakukan untuk menyelesaikan masalah pajak di perusahaan dengan cara yang benar dan legal. Sehingga perusahaan dapat menghitung, memotong, menyetordan melaporpajaknya dengan cara yang benar sesuai ketentuan peraturan perpajakan dan dapat terhindar dari sanksi pajak serta dapat meminimalkan beban pajak dan kerugiannya. Serta mencantumkan perusahaan yang menjadi mitra dari PT. Bank Sulut Cabang Utama sehingga terjadi transparansi pajak yang berguna bagi semua pihak.

2. Dalam hal pelaporan PPh Pasal 25 PT. Bank Sulut Cabang Manado sudah melaporkan tepat waktu dan hal itu sebaiknya dipertahankan. Seperti pada tanggal jatuh tempo jatuh pada hari libur, PT. Bank Sulut Cabang Utama telah mengantisipasinya dengan melapor PPh Pasal 23 dan PPh Pasal 25 terutang sebelum hari libur. Hal ini memang harus dilakukan agar PT. Bank Sulut Cabang Utama dapat terhindar dari sanksi pajak atas keterlambatan pelaporan PPh pasal 25 berupa sanksi bunga sebesar 2\% per bulan dari pajak yang terutang.

\section{DAFTAR PUSTAKA}

Balkaoui, Ahmed Riahi. 2000. Teori Akuntansi Edisi Pertama. Penerbit Salemba Empat : Jakarta.

Hongren, dan Harison. 2007. Akuntansi. Edisi Indonesia. Jakarta : Penerbit Erlangga.

Idris. 2006. Perhitungan dan Perlakuan Akuntansi Pajak Penghasilan Pasal 21 dan Pajak Penghasilan Pasal 25 Pada CV. Haltim Raya Ternate. Skripsi Fakultas Ekonomi Universitas Samratulangi Manado.

Indriantoro, Supomo, 2012. Metode Penelitian Bisnis untuk Akuntansi dan Manajemen. Edisi Pertama. BPFEYogyakarta : Yogyakarta.

Kusuma, Yoga. 2010. Prosedur perhitungan dan pelaporan PPh Pasal 23 atas komisi agen penjualan tiket pada PT. Garuda Indonesia. Skripsi Universitas Gunadarma Jakarta.

Mardiasmo. 2011. Perpajakan. Edisi Revisi. Yogyakarta : Penerbit Andi.

Niswonger, C. Rollin, dkk. 1999. Prinsip-Prinsip Akuntansi Edisi 19 Jilid 1. Penerbit Erlangga: Jakarta.

www.banksulut.co.id

www.kajianpustaka.com

www.pajak.go.id 